\title{
A real-time PCR based survey on acute bee paralysis virus in German bee colonies*
}

\author{
Reinhold SIEDE ${ }^{1}$, Matthias KöNIG ${ }^{1}$, Ralph BÜCHLER ${ }^{2}$, Klaus FAILING $^{3}$, \\ Heinz-Jürgen THIEL ${ }^{1}$ \\ ${ }^{1}$ Institut für Virologie, Fachbereich Veterinärmedizin, Justus-Liebig-Universität Giessen, Frankfurter Str. 107, \\ 35392 Giessen, Germany \\ ${ }^{2}$ Landesbetrieb Landwirtschaft Hessen, Bieneninstitut Kirchhain, Erlenstr. 9, 35274 Kirchhain, Germany \\ ${ }^{3}$ Arbeitsgruppe Biomathematik und Datenverarbeitung, Fachbereich Veterinärmedizin, \\ Justus-Liebig-Universität Giessen, Frankfurter Str. 95, 35392 Giessen, Germany
}

Received 7 March 2008 - Revised 13 June 2008 - Accepted 1 July 2008

\begin{abstract}
The significance of Acute Bee Paralysis Virus (ABPV) for the overwintering capacity of honeybee colonies was studied under field conditions. A case-control study of samples collected in Germany from 2004 to 2006 was performed. Successfully wintering colonies (control) were compared with winter fatalities (cases), using a binary logistic regression model that focused on the pre-winter ABPV burden as the explanatory variable. To quantify the ABPV burden a SYBR Green ${ }^{\circledR}$ based real time PCR protocol was developed. An ABPV-specific primer pair hybridising to the RNA-dependent RNA-polymerase region was used. The assay proved to be ABPV specific and reproducible. ABPV infection was more often observed in colonies that did not survive the winter. In addition, winter fatalities showed higher ABPV burden than surviving colonies. Our findings provide support for a strong and presumably causal relationship between winter mortality, Varroa destructor and ABPV.
\end{abstract}

Apis mellifera /acute bee paralysis virus / real time PCR / relevance / viral load / winter mortality / Varroa destructor

\section{INTRODUCTION}

At least 18 different viruses have been isolated from Apis mellifera L. (Bailey and Ball, 1991; Chen and Siede, 2007). Acute bee paralysis virus (ABPV) is amongst the viruses, which are suspected to be relevant for the beekeeping industry. ABPV is a putative member of the genus Cripavirus, family Dicistroviridae, which belongs to the "picorna-virus-like- superfamily". The single stranded RNA genome has a plus strand orientation (Govan et al., 2000), a size of approximately 9500 nucleotides and consists of two open reading frames (ORF). Both ORFs

Corresponding author: R. Siede, reinhold.siede@1lh.hessen.de

* Manuscript editor: Klaus Hartfelder are separated by an intergenic region that initiates translation at an internal ribosomal entry site. The virus is believed to be involved in the varroosis disease complex, also known as bee parasitic mite syndrome, where the parasitic mite Varroa destructor Anderson \& Trueman functions as a putative vector of the virus (Allen et al., 1986; Tentcheva et al., 2004). Furthermore, the mite can modulate the bee's immune system and thus worsen the course of virus infections (Yang and Cox-Foster, 2005, 2007). Due to the simultaneous appearance of mite and virus under field conditions, it is difficult to separate the effects of both pathogens. In addition to transmission by mites, food exchange is believed to be an important transmission pathway of the virus (Bailey, 1976; Chen et al., 2006). 
The geographical distribution of ABPV is similar to that of A. mellifera. The virus is spread worldwide in bee colonies of European A. mellifera bees (Ellis and Munn, 2005). Little is known about its occurrence in the Asian bee Apis cerana Fabricius, the original host of $V$. destructor. Bumble bees (Bombus spp.) can be experimentally infected (Bailey and Gibbs, 1964), but there are no reports of ABPV in field samples from Bombus Latr.

The biological relevance of bee viruses is still a matter of discussion. Bee colonies can harbour viruses without showing obvious disease symptoms (Anderson and Gibbs, 1988; Dall, 1985; Gauthier et al., 2007). Different approaches have been used to clarify the role of viruses in bee colonies. As early as 1964, Bailey and Gibbs investigated the distribution of viruses in different organ systems. They concluded that the infection of vital organs, such as nervous ganglions or the brain, would lead to obvious harm. A correlation between the infectious dose, the site of infection and the outcome of the viral infection was observed by Bailey (1976): When injected directly into the hemolymph, several hundred ABP virions are lethal, whereas by oral uptake a much higher dose of several tens of thousands of virions is required to produce symptoms. Traditionally, viral loads were determined by antigen detection. Recent developments of PCR protocols allowed higher specificity, improved sensitivity and the possibility of quantification. Moreover, additional information can be obtained. Yue and Genersch (2005) developed a minus-strand-specific RT-PCR to detect productive infections by Deformed Wing Virus (DWV). They showed that virus proliferation was linked to symptoms and consequently resulted in virus linked damage. The introduction of real-time PCR systems was a significant advantage, but to date, not many quantitative PCR protocols for ABPV have been published. We developed a cost efficient and simple SYBR Green ${ }^{\circledR}$ based real time RTPCR with the goal to compare the pre-winter ABPV- loads of bee colonies that died in the following winter with the loads of surviving colonies. ABPV is assumed to be connected with winter mortality: ABPV is a fast killing virus when injected into the hemocoel (Bailey and Gibbs, 1964). ABPV shortens the life span of infected individuals. Affected colonies face serious risks during winter as predicted by mathematical modelling (Martin, 2001). Retrospective studies have found huge amounts of the virus in dead bees from devastated colonies (Ball and Allen, 1988). Therefore this study focused on ABPV. Here results of a field survey in Germany between 2004 and 2006 are reported.

\section{MATERIALS AND METHODS}

\subsection{Bees}

Eleven apiaries managed by 11 sideline beekeepers in the central German region of Hesse were studied between autumn 2004 and spring 2006. Ten colonies per apiary were closely monitored by a professional bee inspector in spring and autumn each year. Live adult bees, approx. $50 \mathrm{~g}$ from each colony, were collected in October of 2004 and 2005, frozen and stored at $-20{ }^{\circ} \mathrm{C}$. The wintering success of each colony was recorded individually by the inspector in spring. At the end of the observation period, the colonies were divided into two groups: the winter fatalities (cases) and the survivors (controls). The ABPV load of the fatality group in all colonies was determined. Three colonies of the control group from each apiary were randomly selected for this assessment. Colony losses from 2004/2005 were replaced by colonies from the same bee yard. The number of Varroa mites per $10 \mathrm{~g}$ bees in each sample was determined by agitating the bees in watery detergent solutions on a mechanical shaker (De Jong et al., 1982).

\subsection{RNA extraction}

The bee samples from each colony were divided into four sub-samples consisting of ten animals each. The complete animals of three subsamples were ground in an ice-cold mortar with a small amount of sea sand and $1 \mathrm{~mL}$ ice-cold water. From the fourth pool of ten bees, only the heads were disrupted in $400 \mu \mathrm{L}$ cold water with a mechanical device (Mixer Mill, Retsch MM300). The crude parts of the mixture were sedimented with two centrifugation steps at $12500 \mathrm{~g}$ and RNA was extracted from $140 \mu \mathrm{L}$ of the liquid supernatant with the QIAamp Viral RNA Mini Kit (Qiagen, Hilden, Germany). Extraction controls with water substituting the supernatant were performed. 
Table I. Diagnostic oligonucleotides.

\begin{tabular}{|c|c|c|c|c|c|}
\hline \multirow{2}{*}{$\begin{array}{l}\text { Primer } \\
\mathrm{A}\end{array}$} & \multicolumn{2}{|l|}{ Sequence } & \multicolumn{2}{|c|}{ Nucleotide position (5' - 3') Accession number } & \multirow{2}{*}{$\begin{array}{l}\text { reference } \\
\text { this study }\end{array}$} \\
\hline & AATGGGCCTATGGACTTTTCTA & Forward & $5360 \rightarrow 5381$ & NC_002548 & \\
\hline $\mathrm{B}$ & AAATCTCCTGCAATAACCTTGG & Reverse & $5517 \rightarrow 5538$ & NC_002548 & this study \\
\hline ABPV14 & TGCAAAGAATGGTGTGAGAACA & Forward & $5257 \rightarrow 5278$ & NC_002548 & this study \\
\hline ABPV15 & CATAATGCAAACATTCAAAGATC & Reverse & $5553 \rightarrow 5575$ & NC_002548 & this study \\
\hline rp1 & AAAAGTTCATTCGTCACCAGAG & Forward & $76 \rightarrow 97$ & NM_001011587 & this study \\
\hline rp2 & TGTCCCTTAAAACGTCTACGAAC & Reverse & $156 \rightarrow 178$ & NM_001011587 & this study \\
\hline ABPV1 & CATATTGGCGAGCCACTATG & Forward & $8102 \rightarrow 8121$ & AF486072 & (Bakonyi et al., 2002) \\
\hline ABPV2 & ССАСТTССАСАСАACTATCG & Reverse & $8482 \rightarrow 8499$ & AF486072 & (Bakonyi et al., 2002) \\
\hline
\end{tabular}

\subsection{Design of diagnostic oligonucleotides}

Using the primer 3 software (Rozen and Skaletsky, 2000) a primer pair, denominated A and $\mathrm{B}$, was derived from the putative domain of the RNA-dependent-RNA-polymerase ( $\mathrm{Rd} \mathrm{Rp}$ ) gene within a published sequence of ABPV (Govan et al., 2000). An outer primer pair (ABPV14-ABPV15) spanning the A - B - sequence was developed for the construction of the recombinant RNA standard. The specificity of primers A and B was tested with Kashmir Bee Virus (KBV)-positive and ABPVnegative bee extracts which were available from a previous survey in 2002/2003 (Siede and Büchler 2004). A third primer pair rp1-rp2, specific for a honeybee gene encoding the ribosomal protein 49 (Ben-Shahar et al., 2003) was developed for normalisation purposes. Sequences are given in Table I.

\subsection{Real time amplification}

The viral target was amplified in real time using the RNA extractions from complete animals as a template. The reactions were prepared using a mixture of reverse transcriptases and polymerases (QuantiTect SYBR Green RT-PCR kit, Qiagen) in a MyiQ Thermo-Cycler (BioRad). Amplification was performed in a total volume of $25 \mu \mathrm{L}$ containing $0.5 \mu \mathrm{M}$ of each primer, $0.25 \mu \mathrm{L}$ enzyme mix and $1 \mu \mathrm{L}$ RNA extract. The conditions for the virusPCR with the primers $\mathrm{A}$ and $\mathrm{B}$ consisted of an initial transcription step of $50{ }^{\circ} \mathrm{C}, 30 \mathrm{~min}$, followed by $95{ }^{\circ} \mathrm{C} 15 \mathrm{~min}$ and 40 cycles of $94{ }^{\circ} \mathrm{C}, 15 \mathrm{~s}, 58^{\circ} \mathrm{C}$ $30 \mathrm{~s}$ and $72{ }^{\circ} \mathrm{C} 30 \mathrm{~s}$. In a separate run, the same extracts were used as templates to amplify the housekeeper RNA with the primer pair rp1-rp2. The reaction mix and the temperature were the same except for an annealing temperature of $54{ }^{\circ} \mathrm{C}$. The sizes of the amplicons were checked by $1.5 \%$ agarose gel electrophoresis ( $75 \mathrm{~V}$ for $1 \mathrm{~h}$ ). The crossing point (CP) of each sample was determined by the maximum curvature approach. All CP-values below 40 were considered as ABPV positive. A non-template control and an interplate calibrator were included in each run.

\subsection{Interplate calibrators}

An amplicon was generated with the oligonucleotides ABPV14 and ABPV15 by end point PCR using Qiagen One Step RT-PCR reagents in order to construct the viral RNA interplate calibrator. An ABPV positive field sample served as template. Reaction conditions corresponded to the manufacturer's recommendations with an annealing temperature of $55{ }^{\circ} \mathrm{C}$. The amplicon was subjected to agarose $(1.5 \%)$ gel electrophoresis ( $75 \mathrm{~V}$ for $1 \mathrm{~h}$ ). The PCR product was excised from the gel, purified with the Qiaquick gel extraction kit (Qiagen, Hilden, Germany) and ligated in the TOPO cloning vector pCR2.1 (Invitrogen, Karlsruhe, Germany). Subsequently it was transformed into chemically competent TOPO10F' Escherichia coli cells. DNA from recombinant plasmids was extracted using the Qiagen Plasmid Mini kit (Qiagen, Hilden, Germany). The sequence identity of the fragment with ABPV was confirmed by sequencing in both directions. The construct was linearised and transcribed in vitro with a T3 RNA polymerase (Stratagene, Amsterdam, the Netherlands). The product was purified with the RNeasy Mini elute kit (Qiagen, Hilden, Germany), and treated with turbo DNAse to remove template DNA (Ambion, Huntington, UK). The interplate calibrator for the rp PCR consisted of a mixture of honeybee nucleic acid extractions. The interplate calibrators were stored in small aliquots at $-20{ }^{\circ} \mathrm{C}$. 


\subsection{Assay performance and sources of variation}

In order to estimate reaction efficiencies, a bee extract heavily loaded with ABPV was serially diluted with RNAse free water over eight magnitudes. Each dilution was amplified in triplicate using the reaction conditions described above.

Experiments were designed to analyse sources of variation of the assay. To determine variations within a PCR run and from run to run, RNA preparations from seven field samples with increasing ABPV loads were used as templates for three PCR runs conducted on three consecutive days. Each PCR reaction was performed in triplicate. In order to estimate variation of parameters of RNA extraction, three separate RNA preparations were generated from single bee homogenates of the same seven field samples. These RNA extracts were analysed by PCR for ABPV and rp. To determine the variability of the sampling procedure, three subsamples consisting of ten bees each were gathered from the seven field-samples, homogenized, extracted and analysed by PCR. Variance components for each level of the assay were estimated by a hierarchical analysis of variance with the BMDP statistical software package version 7.0. The variance components were expressed as standard deviations. These statistical calculations were performed for the $\mathrm{CP}$ values of the target, the housekeeper and the $\log$ transformed $\mathrm{R}$ values.

\subsection{Artificial infection of caged bees}

A crude watery ABPV suspension was prepared from samples infested with ABPV as described by Bailey and Gibbs (1964). From this watery extract, $1 \mu \mathrm{L}$ was injected in $\mathrm{CO}_{2}$ anaesthetised worker bees using a Hamilton syringe and a 30-gauge needle. Bees in groups of 25 animals each were maintained in cages at $28-30{ }^{\circ} \mathrm{C}$ and $75 \%$ relative humidity. All diseased animals showing severe symptoms after three days (trembling, inability to fly, and paralysis) were collected for real time PCR analysis.

\subsection{ABPV-RT PCR on samples}

Extracts of heads from field samples were analysed by end-point PCR according to a published protocol (Bakonyi et al., 2002) with slight modifications. A mixture of reverse transcriptases and taq polymerases was used (Qiagen One Step RT-PCR kit). The lengths of the amplicons were estimated by agarose $(1.5 \%)$ gel electrophoresis ( $75 \mathrm{~V}$ for $1 \mathrm{~h}$ ). A sample was considered positive if an amplicon of the expected size of approx. $400 \mathrm{bp}$ could be detected.

\subsection{Data analysis}

Quantification was done relative to the RNA of the housekeeper rp49. The two interplate calibrators (designated with I and II) were integrated in the analysis. The comparative formula with efficiency correction according to Pfaffl (2001) was applied. To evaluate the need of normalisation an R' value was calculated which represents the corresponding value without normalisation to the housekeeper.

$$
\begin{aligned}
& R=\frac{\left(E_{\text {target }}\right)^{(\triangle C P \text { target(MEANcalibratorI-MEANsample }))}}{\left(E_{\text {ref }}\right)^{(\Delta C P \text { ref(MEANcalibratorII-MEANsample }))}} \\
& R^{\prime}=\left(E_{\text {target }}\right)^{(\Delta C \text { Ptarget(MEANcalibratorI-MEANsample }))}
\end{aligned}
$$

where E: efficiency, CP: crossing point, target: ABPV, ref: reference rp49 RNA.

Efficiencies were determined experimentally with $\mathrm{E}_{\text {target }}=1.82$ and $\mathrm{E}_{\text {ref }}=1.87$.

Mean: arithmetic mean of PCR replicates.

All resulting $\mathrm{R}$ values are expressed as "arbitrary units" by multiplication with $10^{6}$. To approximate to a normal distribution type the data were $\log$ transformed. Since the three PCR reactions per colony were performed from three separate RNA preparations, the $\mathrm{R}$-value of each reaction was calculated separately and then aggregated for each colony (Livak and Schmittgen, 2001).

The ABPV prevalence was calculated as the ratio of ABPV positive colonies to the total colony number under observation. A colony was considered ABPV positive if at least one of the three subsamples had a CP value below 40 in the real time PCR assay. Considering the analysis of head extracts by conventional RT-PCR a colony was termed ABPV positive if an amplicon of approximately $400 \mathrm{bp}$ was observed. Chi square tests, correlation coefficients and analysis of the association between ABPV positivities and mortalities were performed using the statistical programme package SPSS, version 13.0.1 (SPSS Inc., Chicago, Illinois, USA).

For both years the odds ratios of the factor ABPV level were determined by a binary logistic regression procedure after aggregating all $\mathrm{R}$ values coming from the same apiary. The statistical 
analysis of the data was done using the statistical program package BMDP/Dynamic, Release 7.0, (Dixon, 1993).

\section{RESULTS}

\subsection{Development of a real time RT-PCR assay for ABPV}

A primer pair specific for ABPV was designed from the GenBank entry NC_002548. At the time of the primer design, the number of available ABPV sequences was limited to five. Thus, alignment of different GenBank annotations was not helpful in searching conserved regions within the genome of ABPV. The Rd Rp gene is highly conserved within the Picorna-superfamily. We designed a primer pair (denominated $\mathrm{A}$ and $\mathrm{B}$ ), which targeted the $\mathrm{Rd} \mathrm{Rp}$ region. Among the five ABPV entries, no mismatches were observed within the respective region. Data bank searches produced no further sequences homologous to the oligonucleotide pair. Alignment with the KBV entries predicted that the assay would not generate signals from a template containing KBV. This was confirmed experimentally by testing a nucleotide acid preparation that was known to be KBV positive (Siede and Büchler, 2004). The primer pair A-B generates a $179 \mathrm{bp}$ long product with a melting point of $77{ }^{\circ} \mathrm{C}$. The efficiency of the reaction was determined at $82 \%$ using the classical approach of dilution curve and slope calculation using the equation $\mathrm{E}=10^{(-1 / \text { slope })}-1$. The dynamic range covered eight magnitudes with an intra-plate variability of the viral RT PCR of 0.43 (Standard deviation).

\subsection{Normalisation}

Two normalisation approaches were used (see Tab. II): The amount of the viral target was normalised against the volume of RNA template and against the bee specific housekeeping gene rp49, which proved to be suitable as a reference gene (Lourenço et al., 2008). The primer pair, rp1-rp2 flanks an intron within this gene generating a product of $103 \mathrm{bp}$ size from RNA templates and of $244 \mathrm{bp}$ from genomic DNA templates. A Blast-search in GenBank predicted no other homologous sequences than the ribosomal protein gene of the honeybee. The melting point of the RNA derived amplicon amounted to $76.5{ }^{\circ} \mathrm{C}$. In order to assure that the real-time PCR fluorescence only derived from RNA and that no genomic DNA was co-amplified, all PCR products were subjected to gel electrophoresis analysis. In no case, a 244 bp long PCR fragment was observed. The rp1-rp2 PCR had an efficiency of $87 \%$ with a dynamic range that was linear throughout five orders of magnitude with little variation.

\subsection{Assay performance}

Variation sources of the assay were identified by considering the variability between pre-PCR steps, PCR reactions and PCR runs. Variations of the pre-PCR steps were a result of the RNA purification and sampling. The standard deviations of $\mathrm{CP}$ values of the viral target and of the housekeeping gene ranged from 0.06 to 0.444 considering the intra- and inter-PCR variability. A variation factor of $38 \%$ of the R-value was observed (see Tab. III). Inclusion of variation due to the RNA purification step increased the standard deviation of the $\mathrm{CP}$ values for both, the ABPV target and the housekeeping gene. The antilogarithmised variation factor of the $\mathrm{R}$-value rose to 1.905. Considering all steps of the assay, including the sub-sampling-procedure, the variation factor increased tenfold to 10.7 (Tab. III). The ranges of the delta $\mathrm{CP}$ values were low for the PCR steps but high when the pre-PCR steps were included in the analyses (Fig. 1). To balance the variability of the pre-PCR steps, it was decided to invest in the pre PCR steps for the field survey. Therefore, each colony sample was divided into three subsamples, which were extracted and analysed individually.

\subsection{Field survey}

One hundred and ten colonies were observed during the study. Four fatalities occurred in the winter 2004/2005, corresponding to a mortality rate of $3.9 \%$. In the winter of $2005 / 2006$, the mortality was higher with a 
Table II. Comparison of rp-normalised and sample-volume normalised parameters of the ABPV loads in 2004 and 2005. All values are logarithmised.

\begin{tabular}{|c|c|c|c|c|c|c|}
\hline \multicolumn{7}{|c|}{ Normalised against rp49-RNA } \\
\hline & \multicolumn{3}{|c|}{2004} & \multicolumn{3}{|c|}{2005} \\
\hline & Survivors & Fatalities & & Survivors & Fatalities & \\
\hline & (33 colonies) & (4 colonies) & & (33 colonies) & ( 22 colonies) & \\
\hline Mean R-value & 2.59 & 3.07 & \multirow[t]{3}{*}{$P=0.103$} & 2.34 & 5.24 & \multirow[t]{4}{*}{$P<0.001$} \\
\hline SD & 0.67 & 0.38 & & 1.12 & 2.43 & \\
\hline Median R-value & 2.45 & 3.16 & & 2.11 & 4.45 & \\
\hline Odds (95\% Conf.) & \multicolumn{3}{|c|}{$3.14(0.59-16.75)$} & \multicolumn{2}{|c|}{$2.57(1.5-4.4)$} & \\
\hline \multicolumn{7}{|c|}{ Normalised against sample volume } \\
\hline Mean R-value & 1.99 & 2.39 & $P=0.103$ & 2.17 & 5.18 & $P<0.001$ \\
\hline SD & 0.62 & 0.52 & & 1.26 & 2.55 & \\
\hline Median R-value & 1.71 & 2.52 & & 1.4 & 4.57 & \\
\hline Odds (95\% Conf.) & \multicolumn{3}{|c|}{$2.64(0.54-12.8)$} & \multicolumn{2}{|c|}{$2.238(1.48-3.45)$} & \\
\hline
\end{tabular}

SD: standard deviation, 95\% Conf.: 95\% confidence interval, P: probability, Mann-Whitney U test.

Table III. Sources of variation for the PCR assay and the pre-PCR steps. Shown are standard deviations (SD) calculated from the $\mathrm{CP}$ and the R-values by hierarchical analysis of variance.

\begin{tabular}{lcccc}
\hline Variance component: & SD CP ABPV & SD CP rp & SD R & \\
\hline PCR amplification & 0.431 & 0.351 \\
PCR runs & 0.444 & 0.06 & 1.377 & on the PCR plate \\
RNA purification & 1.137 & 0.798 & 1.905 & between PCR plates \\
All steps of the assay, & 3.967 & 1.330 & 10.7 & $\begin{array}{c}\text { all assay levels, } \\
\text { including sampling }\end{array}$ \\
\hline
\end{tabular}

${ }^{1}$ anti-logarithmised standard deviations.

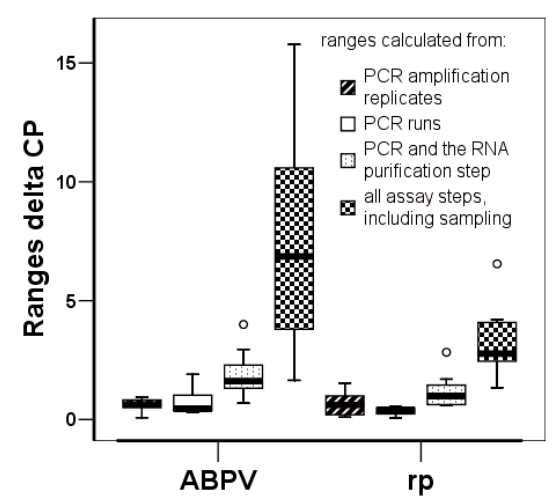

Figure 1. Ranges of delta $\mathrm{CP}$ values for the viral target $\mathrm{ABPV}$ and the control gene rp49 at each step of the assay. Delta $\mathrm{CP}=\mathrm{CP}_{\text {target }}-\mathrm{CP}_{\text {calibratorl }}$, or $=$ $\mathrm{CP}_{\text {housekeeper }}-\mathrm{CP}_{\text {calibratorII }}$ resp. rate of $20 \%$ (22 out of 109 observed colonies). In order to clarify the biological significance of ABPV for winter mortality, we analysed the ABPV RNA positivity rate and the amount of the ABPV load.

\subsubsection{Distribution of ABPV among bee colonies}

Preliminary data indicates that ABPV multiplies in the neural tissues of the bee head. Multiplication in vital tissues could be the crucial point for the outcome of an infection (Bailey and Milne, 1969). Accordingly sampling of bee heads instead of entire corpuses could be advantageous to monitor the distribution of ABPV by conventional RT PCR. In 

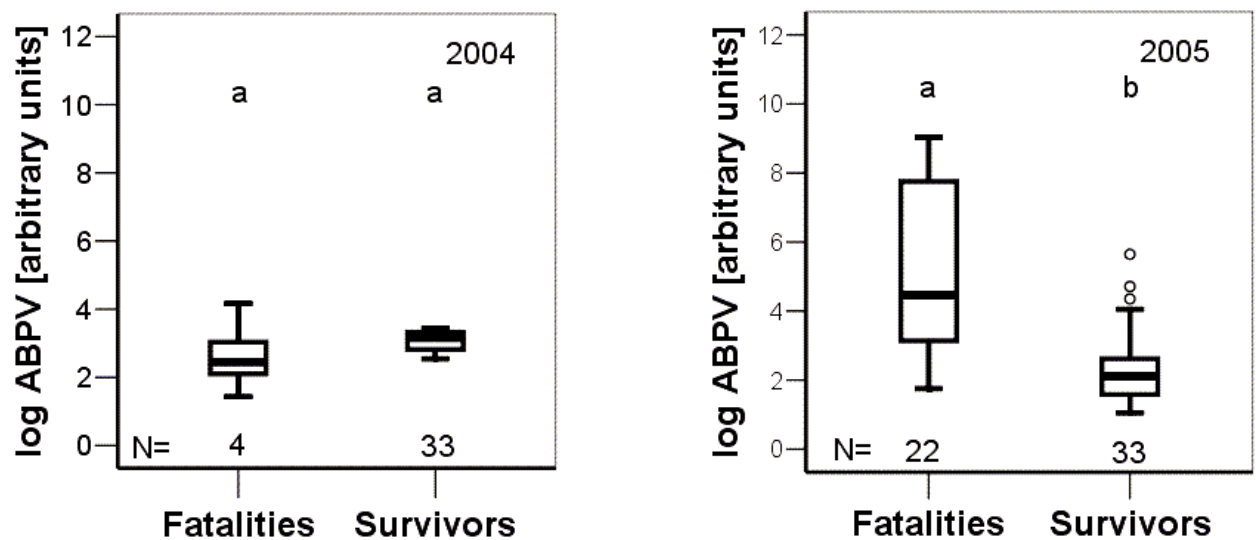

Figure 2. ABPV-load in autumn 2004 (left) and in autumn 2005 (right). Boxes on the left: fatalities, boxes on the right: survivors. Boxes with different letters are significantly different (Dunnett's T3-test, $\alpha=0.05$ ). $\mathrm{N}$ : number of colonies.

our experiments we compared both types of samples (see Tab. IV): When entire bee bodies were tested, $73 \%$ of all colonies were positive for ABPV (27 out of 37) in 2004. This number was even higher with $80 \%$ of all colonies in 2005. A significant linkage between the prewinter ABPV-infection and winter mortality was found for the 2005/2006 season.

The rates for positive RT PCR results were generally lower when heads were used as starting material $(22 \%$ in 2004 and $35 \%$ in 2005 , see Tab. IV). Again, in 2005/2006, the ABPV prevalence was significantly linked with winter mortality. Compared to results from total bodies, the association between head infection and winter losses was even stronger, as indicated by the higher Phi coefficient.

\subsubsection{Assessment of the ABPV loads in bee colonies}

A significant relationship between winter mortality and the total ABPV burden of a colony was found using material from October 2005: The ABPV loads of colonies that perished during winter was approximately 100 times higher in comparison to surviving colonies (see Fig. 2). The odds ratio calculated from the 2005/2006 samples was 2.57 (95\% CI: 1.5-4.4). The method of normalisation (house keeping gene vs. amount of template) did not influence the results in a signifi- cant manner (Tab. II). A significant correlation between the mean ABPV load in the previous autumn and winter losses was not observed for winter 2004/2005 when relatively few colonies perished.

Since no cell culture system for propagation of bee viruses exists it is difficult to determine the infectious dose equivalent to the amount of ABPV genomes detected in bee colonies. To better assess the relevance of the measured amounts of viral RNA we compared the virus loads of the field colonies with virus burdens of experimentally infected bees showing symptoms of acute disease. After experimental infection symptoms usually appeared within 2 d.p.i. and virus loads were determined at 3 d.p.i. Experimentally infected bees showed virus loads about $10^{8}$ times higher than the pre-winter loads of surviving colonies and $10^{6}$ times higher than that of winter fatalities.

\subsubsection{Infestation with $\mathrm{V}$. destructor}

In autumn 2004, the mean infestation rate of all colonies with $V$. destructor amounted to 1.04 mites/10 $\mathrm{g}$ bees and in October 2005 to 13.7 mites/10 $\mathrm{g}$ bees. High mite infestation was linked to high ABPV burdens. In 2005 the correlation between the mite infestation rate and the ABPV level was significant (2004: Spearman Rho $=0.153, P=0.366$, 2005: Spearman Rho $=0.637, P<0.001)$. 
Table IV. Association between the numbers of ABPV positive and ABPV negative colonies and the survivors depending on either the investigation of heads only or total body extracts.

\begin{tabular}{lcccccc}
\hline & & \multicolumn{2}{c}{ Number colonies } & $P^{1}$ & Phi \\
& & & ABPV + & ABPV- & & \\
\hline Complete body $^{2}$ & \multirow{2}{*}{2004} & S & 23 & 10 & 0.197 & 0.212 \\
& & F & 4 & 0 & & \\
& \multirow{2}{*}{2005} & S & 22 & 11 & 0.002 & 0.408 \\
& & F & 22 & 0 & & \\
Head infection $^{3}$ & 2004 & S & 7 & 26 & 0.862 & 0.029 \\
& & F & 1 & 3 & & \\
& 2005 & S & 4 & 29 & $<0.001$ & 0.578 \\
& & F & 15 & 7 & & \\
\hline
\end{tabular}

${ }^{1}$ Pearson's Chi square test, P: asymp. Sig. 2-sided.

${ }^{2}$ Data from the real time PCR assessments with $\mathrm{CP}<40$.

${ }^{3}$ Data from endpoint PCR analysis.

S: survivors, F: fatalities.

Four losses in 2004/2005 and three fatalities in $2005 / 2006$ out of a total of 26 fatalities (27\%) had a relative infestation rate below 10 mites per ten gram bees. All the remaining 19 fatalities showed high infestation rates above 10 mites/10 g bees (see. Fig. 3).

\section{DISCUSSION}

While several protocols for a qualitative detection of ABPV exist (Benjeddou et al., 2001; Bakonyi et al., 2002; Tentcheva et al., 2004; Berenyi et al., 2006; Grabensteiner et al., 2007) only few approaches for the quantification of ABPV have been developed. Allen et al. (1986) developed an indirect ELISA for ABPV, but the main drawback of serological quantification for bee virus research is the limited availability of antisera and the inconsistency between batches of antisera preparations. Real-time PCR overcomes these limitations. Protocols are available for black queen cell virus (BQCV), chronic bee paralysis virus (CBPV), DWV, KBV (Chen et al., 2005, CoxFoster et al., 2007; Gauthier et al., 2007; Ward et al., 2007) and ABPV (Cox-Foster et al., 2007; Gauthier et al., 2007).

In general, the amount of the viral target is measured during amplification and normalised

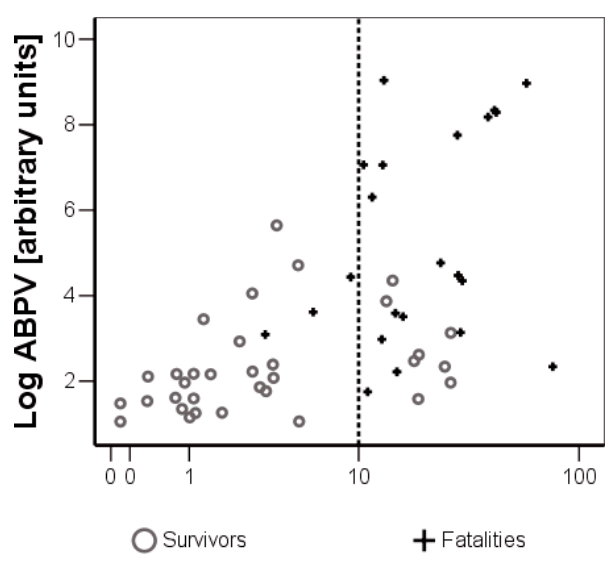

Number V. destructor/ $10 \mathrm{~g}$ bees

Figure 3. Relationship between the number of $V$. destructor in October and the ABPV load for the fatalities and the survivors of the winter 2005/2006. Dotted line: critical mite infestation level according to De Jong (1997).

against a reference value, such as the sample size, the total RNA amount, genomic DNA, reference gene rRNAs (e.g. 18S rRNAs), reference gene mRNAs (e.g. $\beta$-glucan RNA) or alien molecules (Huggett et al., 2005). In this study, we adopted two approaches for normalisation: 1. RNA from the moderately expressed 
rp-gene was chosen, since previous assays demonstrated the suitability of this constitutively expressed housekeeping gene as an invariant endogenous control (Ben-Shahar et al., 2003; Grozinger et al., 2003). 2. Normalisation was performed against sample volume. Both normalisation strategies produced similar findings.

The diagnostic primer pair targeted the putative RNA-dependent RNA polymerase ( $\mathrm{Rd}$ $\mathrm{Rp})$ region of the viral genome. This region was chosen since it is considered to be a conserved genomic region within the picorna-like virus superfamily (Culley et al., 2003). We intended to develop an assay that would detect all ABPV strains while being species specific with particular concern about the distinction between KBV and ABPV, as both viruses share about $70 \%$ identity at the nucleic acid level (De Miranda et al., 2004).

It was shown recently that nucleotide sequence fragments coding for viral RNA can be inserted into the bee genome (Maori et al., 2007). This was demonstrated for Israeli acute bee paralysis virus (IAPV), a member of the Dicistroviridae family. The insertion can mediate resistance to the viral agent. At this point, it cannot be ruled out that sequence exchanges also happen between the bee genome and ABPV. In this hypothetical case, the PCR signals of our assay could be derived from sequences embedded in the bee genome. However, the sequence fragments described by Maori et al. (2007) came from a distant region downstream of the $\mathrm{Rd} \mathrm{Rp}$ region. To confirm the non-existence of sequence exchange and the amplification from viral matter alone, additional experiments will be necessary.

We observed noteworthy variation in the results of our assays, most of which originated from the sampling procedure. Obviously, individual bees show different viral burdens. To compensate for the huge differences in the ABPV content of individual bees, three subsamples of ten bees each were analysed from each colony sample and the three values were averaged. Little is known about the distribution of ABPV within a bee colony. No data are available about the sample size that is required to detect ABPV with a given probability. In previous studies, a sampling size of up to 60 worker bees was used (Bailey et al., 1981; Ball, 1985; Nordström et al., 1999; Bakonyi et al., 2002; Cox-Foster et al., 2007). Tentcheva et al. (2004) and Gauthier et al. (2007) used pools of 100 individuals.

An epidemiological model predicts that the establishment of ABPV is hardly possible in populations that are parasitized for longer periods by $V$. destructor (Martin, 2001). In association with the parasite, the model predicts displacement of the fast killing ABPV by the rather less virulent DWV. We did not monitor the presence of deformed wing virus and therefore it remains unclear whether DWV is the predominant virus. However, despite the fact that honeybees in Germany have been parasitized by $V$. destructor for about 30 years, we observed ABPV in more than $70 \%$ of the colonies in our study. Thus, our results do not support the model of Martin (2001), since obviously, ABPV has not been displaced. However, we surveyed domestic bee colonies. Further studies are required to elucidate the dynamic of virus replacement in a feral bee population.

The relevance of ABPV for bee health was subject of several studies. In the 1960ies, ABPV was described as an economically irrelevant infection of bees (Bailey et al., 1963). First observations of mortality associated with ABPV in nature were reported from the UK in the mid seventies (Bailey, 1976) predating the arrival of $V$. destructor. After the appearance of the mite, many colonies in Europe died from varroosis in the eighties and ABPV was detected frequently in connection with the new parasite. Although it has not yet been proven experimentally, it seems likely that $V$. destructor either vectors $\mathrm{ABPV}$ in a very efficient way as it has been demonstrated for KBV and DWV (Chen et al., 2006) or facilitates an ABPV outbreak by immune suppression as is the case for DWV (Yang and Cox-Foster, 2005). Our findings support the hypothesis of an intrinsic relationship between both, the mite and the virus. Even though it has been reported that the presence of ABPV alone, without mites, can kill honey bee colonies (Bailey, 1976), we did not observe cases of winter mortality that were related to ABPV but independent of mites. 
One critical threshold for winter fatalities due to mites has been determined at 10 mites per $10 \mathrm{~g}$ bees in the fall (De Jong, 1997). In our study, less than a third of the fatalities (27\% of all losses) with mite infestation below the threshold died probably from other causes such as queen loss or starvation. Eight colonies containing more mites than the threshold level survived the winter. Since the sampling was done in October after the end of the winter bee rearing period, mite reinvasion cannot be excluded. Among the fatalities with more than 10 mites per $10 \mathrm{~g}$ bees several colonies harboured less ABPV than survivors with comparable mite numbers. This observation may indicate the relevance of secondary viral infections other than ABPV, such as DWV, KBV, sacbrood virus (SBV), slow paralysis virus (SPV) and putatively BQCV (Chen and Siede, 2007) or may be the result of simultaneous infections with multiple viruses (Berenyi et al., 2006). In addition, parasitisation with $V$. destructor alone can increase winter mortality by modifying the bee physiology (Amdam et al., 2004) such that parasitized bees tend to display the short-lived summer phenotypes with an elevated risk to disappear before the end of winter.

Previous studies diagnosed significant ABPV infections post mortem or after the manifestation of severe symptoms (Ball, 1985; Ball and Allen, 1988; Bakonyi et al., 2002; Berenyi et al., 2006). Our prospective approach confirms the data about the relevance of ABPV from retrospective surveys. We observed that infections with ABPV predated winter losses and elevated ABPV burdens in autumn generally resulted in colony death. Colonies that did not survive had higher infection frequencies in both heads and total bodies and were also characterised by higher total virus loads. Based on our results, the presence of ABPV in fall represents a risk for the overwintering capacity of colonies. Pronounced ABPV infection in autumn appeared to be a predictive marker for winter deaths. Our observations of the relevance of a Dicistrovirus for bee health were corroborated by a North American study (Cox Foster et al., 2007): Recently, the US bee industry suffered heavy colony losses. The syndrome was named colony collapse disorder (CCD). However, correlative evidence linked CCD to IAPV, and not ABPV. Additional experiments with artificial infections of colonies will be required to further elucidate the significance of ABPV for bee health.

\section{ACKNOWLEDGEMENTS}

We wish to thank Marina Meixner for her extensive help in preparing this manuscript. We acknowledge the European Union and the state of Hesse for financial support.

Étude, basée sur la PCR en temps réel, de la paralysie aiguë de l'abeille dans les colonies d'abeilles domestiques d'Allemagne.

Apis mellifera / virus de la paralysie aigue de l'abeille / charge virale / PCR en temps réel / mortalité hivernale / Varroa destructor

\section{Zusammenfassung - Eine Echtzeit-PCR} gestützte Studie über das Akute-BienenParalyse-Virus in deutschen Bienenvölkern. Das Akute-Bienen-Paralyse-Virus (ABPV) gehört zur Gruppe der Insekten infizierenden Picornaähnlichen Viren. Es wird vermutet, dass ABPV ein Mitverursacher des Varroosekrankheitsbildes ist. Post-Mortem-Analysen an europäischen Bienenvölkern zeigten einen Zusammenhang zwischen ABPV und der Milbe Varroa destructor, einem der wichtigsten Bienenparasiten. Jedoch ist die biologische Bedeutung von ABPV noch nicht hinreichend geklärt. Mit dem Ziel, Daten zur Relevanz dieses Virus unter Feldbedingungen zu gewinnen, haben wir von 2004 bis 2006110 Bienenvölker in Hessen (Deutschland) beobachtet. Besonderes Augenmerk wurde auf die Winterfestigkeit der Völker gelegt. Hierbei wurde die vorwinterliche ABPV Last und $V$. destructor-Parasitierungsrate erfolgreich überwinternder Völker mit der Viruslast bzw. der Vermilbung der während des Winters zusammenbrechenden Völker verglichen. Die Völker wurden regelmäßig vor und nach dem Winter von einem professionellen Bieneninspektor beurteilt und beprobt. Die Bienenproben wurden zur Feststellung der ABPV Last und der Parasitierungsrate benutzt. Zur Bestimmung der ABPV Belastungen wurde ein Echtzeit PCR Protokoll entwickelt.

Während des Winters 2004/2005 traten wenige Volkszusammenbrüche auf (Verlustrate 3,9\%). Ein Jahr später wurde eine Mortalität von $20 \%$ beobachtet. ABPV wurde in beiden Jahren nachgewiesen, jedoch trat das Virus vor dem Winter 
2005/2006 häufiger auf als im Herbst 2004. In 2005 unterschied sich die ABPV Infektionsrate der überwinternden Völker signifikant von der Rate der Winterverluste. Gleichermaßen war die ABPV Last der Winterverluste 2005/2006 signifikant höher als diejenige der überlebenden Völker. Erhöhte ABPV Belastungen gingen einher mit erhöhtem Befall mit $V$. destructor. ABPV Infektionen erwiesen sich als Risikofaktor für den Überwinterungserfolg der Bienenvölker. Völker, die den Winter nicht überstanden, waren bereits im Herbst häufiger und mit mehr ABPV belastet als jene, die erfolgreich überwinterten. Diese Studie zeigt den engen Zusammenhang zwischen $V$. destructor, ABPV und Volksmortalität.

\section{Apis mellifera / Akutes-Bienen-Paralyse-Virus / Echtzeit-PCR / Bedeutung / Viruslast / Völker- sterben / Varroa destructor}

\section{REFERENCES}

Allen M.F., Ball B.V., White R.F., Antoniw J.F. (1986) The detection of acute paralysis virus in Varroa jacobsoni by the use of a simple indirect ELISA, J. Apic. Res. 25, 100-105.

Amdam G.V., Hartfelder K., Norberg K., Hagen A., Omholt S.W. (2004) Altered physiology in worker honey bees (Hymenoptera: Apidae) infested with the mite Varroa destructor (Acari: Varroidae): A factor in colony loss during overwintering? J. Econ. Entomol. 97, 741-747.

Anderson D.L., Gibbs A.J. (1988) Inapparent virus infection and their interactions in pupae of the honey bee (Apis mellifera Linnaeus) in Australia, J. Gen. Virol. 69, 1617-1625.

Bailey L. (1976) Viruses attacking the honey bee, Adv. Virus Res. 20, 271-304.

Bailey L., Gibbs A.J. (1964) Acute infection of bees with paralysis virus, J. Insect Pathol. 6, 395-407.

Bailey L., Milne R.G. (1969) The multiplication regions and interaction of acute and chronic bee paralysis viruses in adult honey bees, J. Gen. Virol. 4, 9-14.

Bailey L., Ball B.V. (1991) Honey bee pathology, Academic Press, London.

Bailey L., Gibbs A.J., Woods R.D. (1963) Two viruses from adult honey bees (Apis mellifera L.), Virology 21, 390-395.

Bailey L., Ball B., Perry J.N. (1981) The prevalence of viruses of honey bees in Britain, Ann. Appl. Biol. 97, 109-118.

Bakonyi T., Farkas R., Szendroi A., Dobos-Kovacs M., Rusvai M. (2002) Detection of acute bee paralysis virus by RT-PCR in honey bee and Varroa destructor field samples: Rapid screening of representative Hungarian apiaries, Apidologie 33, 63-74.
Ball B.V. (1985) Acute paralysis virus isolates from honeybee colonies infested with Varroa jacobsoni, J. Apic. Res. 24, 115-119.

Ball B.V., Allen M.F. (1988) The prevalence of pathogens in honey bee (Apis mellifera) colonies infested with the parasitic mite Varroa jacobsoni, Ann. Appl. Biol. 113, 237-244.

Ben-Shahar Y., Leung H., Pak W.L., Sokolowski M.B., Robinson G.E. (2003) cGMP-dependent changes in phototaxis: a possible role for the foraging gene in honey bee division of labor, J. Exp. Biol. 206, 2507-2515.

Benjeddou M., Leat N., Allsopp M., Davison S. (2001) Detection of acute bee paralysis virus and black queen cell virus from honeybees by reverse transcriptase PCR, Appl. Environ. Microbiol. 67, 2384-2387.

Berenyi O., Bakonyi T., Derakhshifar I., Koglberger H., Nowotny N. (2006) Occurrence of six honeybee viruses in diseased Austrian apiaries, Appl. Environ. Microbiol. 72, 2414-2420.

Chen Y.P., Siede R. (2007) Honey bee viruses, Adv. Virus Res. 70, 33-80.

Chen Y.P., Higgins J.A., Feldlaufer M.F. (2005) Quantitative real-time reverse transcription-PCR analysis of deformed wing virus infection in the honeybee (Apis mellifera L.), Appl. Environ. Microbiol. 71, 436-441.

Chen Y., Evans J., Feldlaufer M. (2006) Horizontal and vertical transmission of viruses in the honey bee, Apis mellifera, J. Invertebr. Pathol. 92, 152-159.

Cox-Foster D.L., Conlan S., Holmes E.C., Palacios G., Evans J.D., Moran N.A., Quan P.L., Briese T., Hornig M., Geiser D.M., Martinson V., Vanengelsdorp D., Kalkstein A.L., Drysdale A., Hui J., Zhai J., Cui L., Hutchison S.K., Simons J.-F., Egolm M., Pettis J.S., Lipkin W.I. (2007) A metagenomic survey of microbes in honey bee colony collapse disorder, Science 318, 283-287.

Culley A.I., Lang A.S., Suttle C.A. (2003) High diversity of unknown picorna-like viruses in the sea, Nature 424, 1054-1057.

Dall D.J. (1985) Inapparent infection of honey bee pupae by Kashmir and sacbrood bee viruses in Australia, Ann. Appl. Biol. 106, 461-468.

De Jong D. (1997) Mites: Varroa and other parasites of brood, in: Morse R.M., Flottum K. (Eds.), Honey Bee Pests, Predators and diseases, A. I. Root Company, Medina, pp. 279-327.

De Jong D., De Andrea Roma D., Goncalves L.S. (1982) A comparative analysis of shaking solutions for the detection of Varroa jacobsoni on adult honeybees, Apidologie 13, 297-306.

De Miranda J.R., Drebot M., Tyler S., Shen M., Cameron C.E., Stoltz D.B., Camazine S.M. (2004) Complete nucleotide sequence of Kashmir bee 
virus and comparison with acute bee paralysis virus, J. Gen. Virol. 85, 2263-2270.

Dixon W.J. (1993) BMDP Statistical Software Manual, Volumes 1 and 2. University of California Press, Berkeley, Los Angeles, London.

Ellis J.D., Munn P. (2005) The worldwide health status of honey bees, Bee World 86, 88-101.

Gauthier L., Tentcheva D., Tournaire M., Dainat B., Cousserans F., Colin M.E., Bergoin M. (2007) Viral load estimation in asymptomatic honey bee colonies using the quantitative RT-PCR technique, Apidologie 38, 426-435.

Govan V.A., Leat N., Allsopp M., Davison S. (2000) Analysis of the complete genome sequence of acute bee paralysis virus shows that it belongs to the novel group of insect-infecting RNA Viruses, Virology 277, 457-463.

Grabensteiner E., Bakonyi T., Ritter W., Pechhacker H., Nowotny N. (2007) Development of a multiplex RT-PCR for the simultaneous detection of three viruses of the honeybee (Apis mellifera L.): Acute bee paralysis virus, black queen cell virus and sacbrood virus, J. Invertebr. Pathol. 94, 222225.

Grozinger C.M., Sharabash N.M., Whitfield C.W., Robinson G.E. (2003) Pheromone-mediated gene expression in the honeybee brain, Proc. Natl. Acad. Sci. USA 100, Suppl. 2, 14519-14525.

Huggett J., Dheda K., Bustin S., Zumla A. (2005) Realtime RT-PCR normalisation; strategies and considerations, Genes Immun. 6, 279-284.

Livak K.J., Schmittgen T.D. (2001) Analysis of relative gene expression data using real time quantitative PCR and the $2_{T}^{-\Delta \Delta C}$ Method, Methods 25, 402-408.

Lourenço A.P., Mackert A., dos Santos Christino A., Simões Z.L.P. (2008) Validation of reference genes for gene expression studies in the honey bee, Apis mellifera, by quantitative real-time RT-PCR, Apidologie 39, 372-385.

Maori E., Tanne E., Sela I. (2007) Reciprocal sequence exchange between non-retro viruses and hosts leading to the appearance of new host phenotypes, Virology 362, 342-349.

Martin S.J. (2001) The role of Varroa and viral pathogens in the collapse of honeybee colonies: a modelling approach, J. Appl. Ecol. 38, 10821093.

Nordström S., Fries I., Aarhus A., Hansen H., Korpela S. (1999) Virus infections in Nordic honey bee colonies with no, low or severe Varroa jacobsoni infestations, Apidologie 30, 475-484.

Pfaffl M. (2001) A new mathematical model for relative quantification in real-time RT-PCR, Nucleic Acids Res. 29, e45.

Rozen S., Skaletsky H. (2000) Primer3 on the WWW for general users and for biologist programmers, in: Krawetz S., Misener S. (Eds.), Bioinformatics Methods and Protocols: Methods in Molecular Biology, Humana Press, Totowa, NJ, pp. 365-386.

Siede R., Büchler R. (2004) Erstbefund des KaschmirBienen-Virus in Hessen, Berl. Munch. Tierarztl. Wochenschr. 117, 12-15.

Tentcheva D., Gauthier L., Jouve S., CanabadyRochelle L., Dainat B., Cousserans F., Colin M.E., Ball B.V., Bergoin M. (2004) Prevalence and seasonal variations of six bee viruses in Apis mellifera L. and Varroa destructor mite populations in France, Appl. Environ. Microbiol. 70, 7185-7191.

Ward L., Waite R.B.N., Fisher T., Pescod K., Thompson H., Chantawannakul P., Brown M. (2007) First detection of Kashmir bee virus in the UK using real-time PCR, Apidologie 38, 181191.

Yang X., Cox-Foster D.L. (2005) Impact of an ectoparasite on the immunity and pathology of an invertebrate: Evidence for host immunosuppression and viral amplification, Proc. Natl. Acad. Sci. USA 102, 7470-7475.

Yang X., Cox-Foster D. (2007) Effects of parasitization by Varroa destructor on survivorship and physiological traits of Apis mellifera in correlation with viral incidence and microbial challenge, Parasitology 134, 405-412.

Yue C., Genersch E. (2005) RT-PCR analysis of deformed wing virus in honey bees (Apis mellifera) and mites (Varroa destructor), J. Gen. Virol. 86, 3419-3424. 